\title{
Quantitative RNA and DNA Gene Amplification Can Rapidly Monitor HIV Infection and Antiviral Activity in Cell Cultures
}

\author{
Mark A. Winters, Mark Holodniy, David A. Katzenstein, \\ and Thomas $C$. Merigan \\ Center for AIDS Research, Stanford University Medical Center, Stanford, \\ California 94305-5107
}

\begin{abstract}
We have developed a quantitative gene amplification procedure to assess the replication of human immunodeficiency virus (HIV) in cell cultures and evaluate the effect of drugs on viral replication. Increases in HIV gag RNA and DNA in phytohemagglutinin-stimulated normal peri-pheral blood mononuclear cells (PBMC) infected with HIV at very low multiplicity of infection paralleled the production of HIV p24 antigen in culture supernatants. Quantitative gene amplification was able to monitor the accumulation of viral nucleic acids in control cultures and demonstrate the effect of various concentrations of azidothymidine (AZT) on the replication of both AZT-sensitive and -resistant strains of HIV. The sensitivity of patient-derived virus strains to AZT could also be successfully measured by these procedures. The results of our studies suggest that quantitative measurement of HIV gag RNA and DNA can be used to monitor the kinetics of viral replication, antiviral activity, viral drug resistance, and mechanism of drug action.
\end{abstract}

$\mathbf{M}$ easuring the replication of human immunodeficiency virus (HIV) in vitro is essential for assessing the infectivity of various specimens and in examining the potency of compounds that may inhibit viral replication. Secreted structural proteins such as p24 antigen or the enzymatic activity of viral reverse transcriptase ${ }^{(1,2)}$ have been widely used to assess viral replication in vitro. However, recent reports have demonstrated that in certain situations a dissociation between integration, translation, and transcription of viral nucleic acids can occur. ${ }^{(3,4)}$ In evaluating the effect of antiviral agents on HIV, the presence or accumulation of viral nucleic acids should be examined in addition to structural or enzymatic markers to assess fully the activity of an antiviral compound and examine the mechanism by which it acts.

The presence of HIV nucleic acids in cells has primarily been measured directly by in situ hybridization or Southern blot analysis. ${ }^{(5-7)}$ With the application of the polymerase chain reaction (PCR) to assess the presence of HIV,$(8,9)$ very small amounts of HIVspecific nucleic acids can be detected. Recent studies have used quantitative gene amplification methods to measure proviral copy number in patient peripheral blood mononuclear cells (PBMC). ${ }^{(10-12)}$ We have applied a quantitative PCR technique to examine the kinetics of HIV replication in vitro and to assess the effect of antiviral drugs on the accumulation of HIV gag RNA and DNA. Our results suggest that this technique may be useful in assessing infectivity, antiviral activity, viral resistance, and mechanism of drug action in an in vitro assay system.

\section{MATERIALS AND METHODS}

\section{Cells and Viruses}

PBMC from healthy HIV seronegative donors were isolated on FicollHypaque gradients and washed twice with phosphate-buffered saline (PBS, $\mathrm{pH}$ 7.2). The isolated PBMC were cultured for 3 days in complete medium (RPMI $+15 \%$ fetal bovine serum $+5 \%$ $\mathrm{IL}-2+1 \%$ penicillin-streptomycin) containing 3-5 $\mu \mathrm{g} / \mathrm{ml}$ phytohemagglutinin (PHA). The cells (PHA blasts) were then washed twice and resuspended in complete medium at $1 \times 10^{6}$ cells $/ \mathrm{ml}$.

Stocks of HIV strains IIIb and strain 691(13) (kindly provided by D. Richman) were prepared by infecting PHA blasts with virus stocks and harvesting the supernatant 4-14 days later. For production of patient virus stocks, blood was collected with informed consent and the PBMC isolated over Ficoll-Hypaque gradients. The patient PBMC were then cocultured with an equal number of PHA blasts in complete medium for 4-14 days. The supernatants were collected and stored at $-70^{\circ} \mathrm{C}$, and titered in PHA blasts prior to use in experiments. One tissue culture infectious dose (TCID) was defined as the highest 10 -fold dilution of virus stock added to $1 \times 10^{6} \mathrm{PHA}$ blasts that yielded a positive p24 test (greater than $25 \mathrm{pg} / \mathrm{ml}$ ) in the culture supernatant after 7 days. 


\section{HIV Cultures}

Approximately $2 \times 10^{7}$ PHA blasts were incubated in $20 \mathrm{ml}$ of complete medium containing various concentrations of AZT for $4-6 \mathrm{hr}$ in $50-\mathrm{ml}$ centrifuge tubes. HIV was then added to the cultures and incubated for 1-2 hr at $37^{\circ} \mathrm{C}$. The cells were then washed three times with PBS, and resuspended in approximately $20 \mathrm{ml}$ of complete medium containing the appropriate amount of drug. The cells were cultured in $25-\mathrm{cm}^{2}$ flasks for the duration of the experiment.

\section{Sampling Procedures}

At each sampling time point, the cells in each culture were thoroughly resuspended and $5 \mathrm{ml}$ of the culture was removed. The culture sample was centrifuged for $5 \mathrm{~min}$ at $500 \mathrm{~g}$; the supernatant was removed and stored at $-20^{\circ} \mathrm{C}$ for p24 assay, and the cell pellet was resuspended in $15 \mathrm{ml}$ of PBS and centrifuged as before to remove extracellular virus particles. The supernatant was discarded, and the pellet was resuspended in $1 \mathrm{ml}$ of PBS and transferred to a $1.5-\mathrm{ml}$ microcentrifuge tube. The cells were again pelleted at $6000 \mathrm{~g}$ for $30 \mathrm{sec}$, the supernatant removed, and the pellet resuspended in $275 \mu$ l of PBS. The cell suspension was then divided into two aliquots: $200 \mu \mathrm{l}$ was removed and placed into another $1.5-\mathrm{ml}$ microcentrifuge tube containing $200 \mu \mathrm{l}$ of $5 \mathrm{M}$ guanidine isothiocyanate for later RNA extraction, and the remaining $75 \mu \mathrm{l}$ was diluted to $200 \mu \mathrm{l}$ with PBS for later DNA extraction. Both cell samples were stored at $-70^{\circ} \mathrm{C}$ until the end of the experiment.

\section{p24 Antigen Measurement}

The amount of HIV p24 antigen in the supernatant of each culture was determined using a DuPont p24 antigen kit. The assay was performed according to manufacturer's instructions.

\section{Nucleic Acid Purification}

RNA was purified by the method described by Chomczynski and Sacchi. ${ }^{(14)}$ Briefly, $15 \mu \mathrm{l}$ of $3 \mathrm{M}$ sodium acetate was added to each $200-\mu$ l cell sample stored in guanidine isothiocyanate. The sample was then extracted with $200 \mu \mathrm{l}$ of water-saturated phenol and $40 \mu \mathrm{l}$ of chloroform-isoamyl alcohol (49:1). After being held on ice for $20 \mathrm{~min}$, the samples were centrifuged at $6000 \mathrm{~g}$ for $20 \mathrm{~min}$ at $4^{\circ} \mathrm{C}$. The aqueous layer was transferred to a clean microcentrifuge tube and the RNA was precipitated with $500 \mu \mathrm{l}$ of isopropanol for $1 \mathrm{hr}$ at $-20^{\circ} \mathrm{C}$. The RNA was pelleted and resuspended in $200 \mu \mathrm{l}$ of guanidine. The RNA was precipitated again with $200 \mu \mathrm{l}$ of isopropanol for $1 \mathrm{hr}$ at $-20^{\circ} \mathrm{C}$, pelleted, and washed once with $200 \mu \mathrm{l}$ of $75 \%$ ethanol. The final RNA pellet was then dried and resuspended in 10-20 $\mu \mathrm{l}$ of diethylpyrocarbonatetreated water, and the amount of RNA in each sample was quantitated by spectrophotometry. Preliminary experiments demonstrated that specimens extracted by this method were free of contaminating DNA (data not shown).

DNA was isolated from cell pellets by digestion with proteinase $\mathrm{K}$ buffer $(0.1 \mathrm{mg} / \mathrm{ml}$ proteinase $\mathrm{K}, 10 \mathrm{mM}$ Tris$\mathrm{HCl}, \mathrm{pH} 8.3,2.5 \mathrm{~mm} \mathrm{MgCl}_{2}, 50 \mathrm{~mm}$ $\mathrm{KCl}$, and $0.45 \%$ Tween-20) overnight at $55^{\circ} \mathrm{C}$. The samples were then heated to $95^{\circ} \mathrm{C}$ for $5 \mathrm{~min}$, and the DNA was precipitated by the addition of $500 \mu \mathrm{l}$ of absolute ethanol. After $1 \mathrm{hr}$ at $-20^{\circ} \mathrm{C}$, the DNA was pelleted, washed once with $200 \mu \mathrm{l}$ of $75 \%$ ethanol, and pelleted again. The DNA pellets were dried and resuspended in 20-50 $\mu \mathrm{l}$ of water, and the amount of DNA in each sample was quantitated by spectrophotometry.

\section{Cene Amplification}

RNA samples were reverse-transcribed prior to PCR amplification. One microgram of RNA was incubated with 10 pmoles of random hexamers, $0.5 \mathrm{~mm}$ of each dNTP, 2.5 units of RNasin, and 5 units of murine leukemia virus (MuLV) reverse transcriptase (Bethesda Research Labs) in $10 \mu \mathrm{l}$ of amplification buffer (10 mM Tris $\mathrm{HCl}(\mathrm{pH} 8.3)$, $2.5 \mathrm{mM} \mathrm{MgCl}_{2}, 0.02 \%$ gelatin, and 50 $\mathrm{mM} \mathrm{KCl}$ ) for $30 \mathrm{~min}$ at $42^{\circ} \mathrm{C}$, then at $95^{\circ} \mathrm{C}$ for $5 \mathrm{~min}$.

PCR amplification was performed on the reverse-transcribed RNA samples and on $1 \mu \mathrm{g}$ of each DNA sample. Each reaction mixture contained the nucleic acid sample, 50 pmoles of primers SK39 and biotinylated SK38 (Synthetic Genetics, San Diego, CA), $200 \mu \mathrm{M}$ each of dNTP, and 2.5 units of AmpliTaq DNA polymerase (Perkin-
Elmer Cetus) in $100 \mu \mathrm{l}$ of amplification buffer. All samples were then overlayed with approximately $50 \mu \mathrm{l}$ of light mineral oil and amplified for 30 cycles on a Perkin-Elmer Model 480 with the following parameters: $95^{\circ} \mathrm{C}$ for $10 \mathrm{sec}$, $55^{\circ} \mathrm{C}$ for $30 \mathrm{sec}$, and $72^{\circ} \mathrm{C}$ for $30 \mathrm{sec}$, followed by a 10 -min extension step at $72^{\circ} \mathrm{C}$.

\section{Quantitation of PCR Product}

A nonisotopic enzyme-based assay was performed to quantitate the amount of amplified DNA in each sample. Microtiter plates were coated with $100 \mu \mathrm{l}$ of a $0.1 \mathrm{mg} / \mathrm{ml}$ avidin solution prepared in $0.05 \mathrm{M}$ sodium carbonate $(\mathrm{pH}$ 9.6). After overnight incubation at room temperature, the avidin solution was discarded and the wells were filled with a blocking solution consisting of $5 \times$ Denhardt's solution, $1 \%$ gelatin, and $0.25 \mathrm{mg} / \mathrm{ml}$ herring sperm DNA. After at least $18 \mathrm{hr}$ at $4^{\circ} \mathrm{C}$, the blocking solution was discarded and $65 \mu \mathrm{l}$ of hybridization solution (5x SSPE, 5x Denhardt's solution) containing 1 pmole of horseradish peroxidase (HRP)-labeled SK19 was added to each well.

Immediately prior to assay, the PCR reaction products were heated to $95^{\circ} \mathrm{C}$ for $5 \mathrm{~min}$, then rapidly cooled to $4^{\circ} \mathrm{C}$. Five microliters of each PCR reaction product was then added to each well and the plate was incubated for 1-2 hr at $42^{\circ} \mathrm{C}$ to allow for capture and hybridization. The plate was then washed 20 times with $300 \mu \mathrm{l}$ of PBS containing $0.05 \%$ Tween-20. The HRP substrate $o$-phenylenediamine was prepared at $0.6 \mathrm{mg} / \mathrm{ml}$ in $0.1 \mathrm{M}$ citrate buffer (pH 5.5), and $150 \mu \mathrm{l}$ of this solution was added to each well. After 10 min at room temperature, the reaction was stopped with $100 \mu$ l of $1 \mathrm{~N}$ sulfuric acid, and the optical density of each well was measured at $490 \mathrm{~nm}$. The log DNA or RNA copy number for each sample was then determined by comparing the optical density value for each sample to a standard curve generated from parallel amplification of dilutions of $\mathrm{ACH} 2$ cell $\mathrm{DNA}^{(15)}$ or an RNA gag gene construct. ${ }^{(16)}$

\section{RESULTS}

\section{Quantitation of PCR Product}

The use of biotinylated primers during the gene amplification step allowed 
the use of a microtiter plate-based detection system. ${ }^{(15)}$ Avidin attached to microtiter wells captured the biotinylated PCR product, which could then be quantified using a HRP-labeled probe. The number of input HIV gag RNA or DNA copies in each PCR reaction was determined from standard curves generated from serial dilutions of $\mathrm{ACH} 2$ cell DNA or an RNA gag construct. A strict log-linear relationship existed between the copy number and the optical density in this assay system such that approximately $30-50,000$ copies could be accurately measured. The range of sensitivity in this assay is similar to that seen with methods using radiolabeled probes such as dot blots or Southern blots. ${ }^{(17-19)}$ In these experiments, single RNA or DNA samples from each culture were amplified because our previous work $(15,16)$ showed a high reproducibility between replicate samples in this assay system.

\section{Detection of HIV Replication and Drug Effect}

We initially used laboratory-adapted strains of HIV to assess the ability of quantitative PCR to measure HIV replication and the effect of AZT on viral growth. Preliminary experiments examining the effect of inoculum size indicated that 10-100 TCID were sufficient to provide measurable p24, RNA, and DNA signals in a 7-day period that could be used effectively to compare the effect of various concentrations or AZT on replication (data not shown). In addition, while quantitative values (e.g., p24 antigen concentration on DNA copy number) were different when isolates were cultured on different weeks (primarily due to differences in PHA blasts), the overall relationship between the control and the drug-treated cultures was consistent on a week-to-week basis (data not shown).

For drug sensitivity experiments, PHA blasts were infected with approximately 100 TCID of either the AZTsensitive strain IIIb or the AZT-resistant strain 691 in the presence or absence of various concentrations of AZT. Cells and supernatant were collected at various times and later analyzed for HIV nucleic acids and p24 antigen, respectively. Figure 1 shows the results of p24 and gene amplification measurements to assess the inhibition of replication by AZT. DNA and p24 measurements demonstrate that the replication of HIV strain IIIb was significantly inhibited by 0.01-0.1 $\mu \mathrm{M}$ AZT, but greater amounts of AZT were required to inhibit RNA accumulation significantly. HIV strain 691 was significantly less inhibited by AZT, requiring concentrations of at least $0.1 \mu \mathrm{M}$ AZT to slow replication as measured by p24 antigen. Accumulation of HIV RNA and DNA were not significantly inhibited by as much as $1.0 \mu \mathrm{M} \mathrm{AZT}$.

\section{Assessment of Viral Replication and AZT Sensitivity in HIV Isolated from HIV-Seropositive Individuals}

Virus stocks were prepared from the PBMC of HIV-seropositive individuals, titered, and used to infect PHA blasts in the presence or absence of AZT. HIV gag RNA, DNA, and p24 antigen production in these cultures were evaluated as previously described for HIV strains IIlb and 691. Figure 2 shows the p24, RNA, and DNA assay results from cultures of PHA blasts infected with 100 and 50 TCID of virus isolated from patient L2 or patient JR, respectively. Patient $\mathrm{L} 2$ had been diagnosed with the acquired immunodeficiency syndrome (AIDS) and had been on AZT therapy for more than 2 years when the virus stock was generated. This virus replicated even in the presence of $1 \mu \mathrm{M} \mathrm{AZT}$, indicating a relatively high level of resistance to AZT. Patient JR was asymptomatic and had never received AZT treatment. The growth of virus from this patient appeared to be relatively sensitive to AZT, as it was completely inhibited by 0.1 $\mu \mathrm{M}$ AZT. For both patients, all three markers of HIV replication produced similar AZT sensitivity results that were related to their clinical history.

\section{DISCUSSION}

We investigated the utility of measuring HIV gag RNA and DNA to assess the replication of HIV in cell cultures and to evaluate the effect of drugs on viral replication. Using quantitative PCR techniques, we found that the increases in HIV gag RNA and DNA in PHA blasts infected with HIV paralleled the production of HIV p24 antigen in culture supernatants in our short-term assay system. The use of these markers to measure replication of HIV at a rela- tively low multiplicity of infection (10-100 TCID) within a short time frame ( $\leq 7$ days) demonstrated the replicative capacity of the virus in control cultures and the overall effect of antiretroviral drugs.

While the relationship between the p24, RNA, and DNA measurements was similar in each instance, the change in HIV gag RNA expression in the cells preceded and predicted the ultimate changes in p24 antigen and HIV DNA levels within 1-3 days. These results were not unexpected, because the production of structural and regulatory RNA species precedes the production of structural proteins. ${ }^{(20)}$ The ineffectiveness of lower AZT concentrations on the replication of both AZT-sensitive and -resistant strains was also evident earlier by RNA analysis. The use of HIV RNA to assess infectivity and antiviral activity may be ultimately more sensitive and allow conclusions to be made days earlier than p24 or DNA measurements.

We used titered virus stocks that had been passaged once through PHA blasts to assess the utility of our assay system. In assessing the effect of AZT on the patient-derived virus, we were limited to a lower TCID when testing one strain (JR) because a single-pass stock that possessed a high virus titer could not be generated. Despite the very low multiplicity of infection used to infect these cultures, we were still able to quantitate viral replication within 3-7 days. The sensitivity of PCR systems might allow relatively small quantities of virus in primary specimens (e.g., plasma, serum, CSF, etc.) to be detected within a short time. A more rigorous analysis of the effect of a varying inoculum size and of different inherent virus growth rates on the drug sensitivity measurements in this type of in vitro system would be needed to further this application of PCR techniques.

Using measurements of HIV nucleic acids to assess viral replication may also be useful in examining the mechanism of action of antiretroviral drugs. Although not evident in our studies using AZT, in some instances the release of p24 antigen into culture supernatants can continue to occur even though HIV mRNA transcription ${ }^{(3)}$ and the production of in- 
fectious virus particles ${ }^{(3,4)}$ is inhibited. In addition, the integration of HIV DNA in the absence of productive viral replication has been shown to occur, ${ }^{(3)}$ an event that could be detected by nucleic acid evaluation but not by measuring the production of structural proteins. The sole use of structural proteins such as p24 antigen to assess viral replication could thus obscure the effectiveness of an antiviral drug that primarily affects the transcription of certain types of viral RNA or DNA.

Our results suggest that gene amplification techniques may be effectively
HIV Strain IIIb
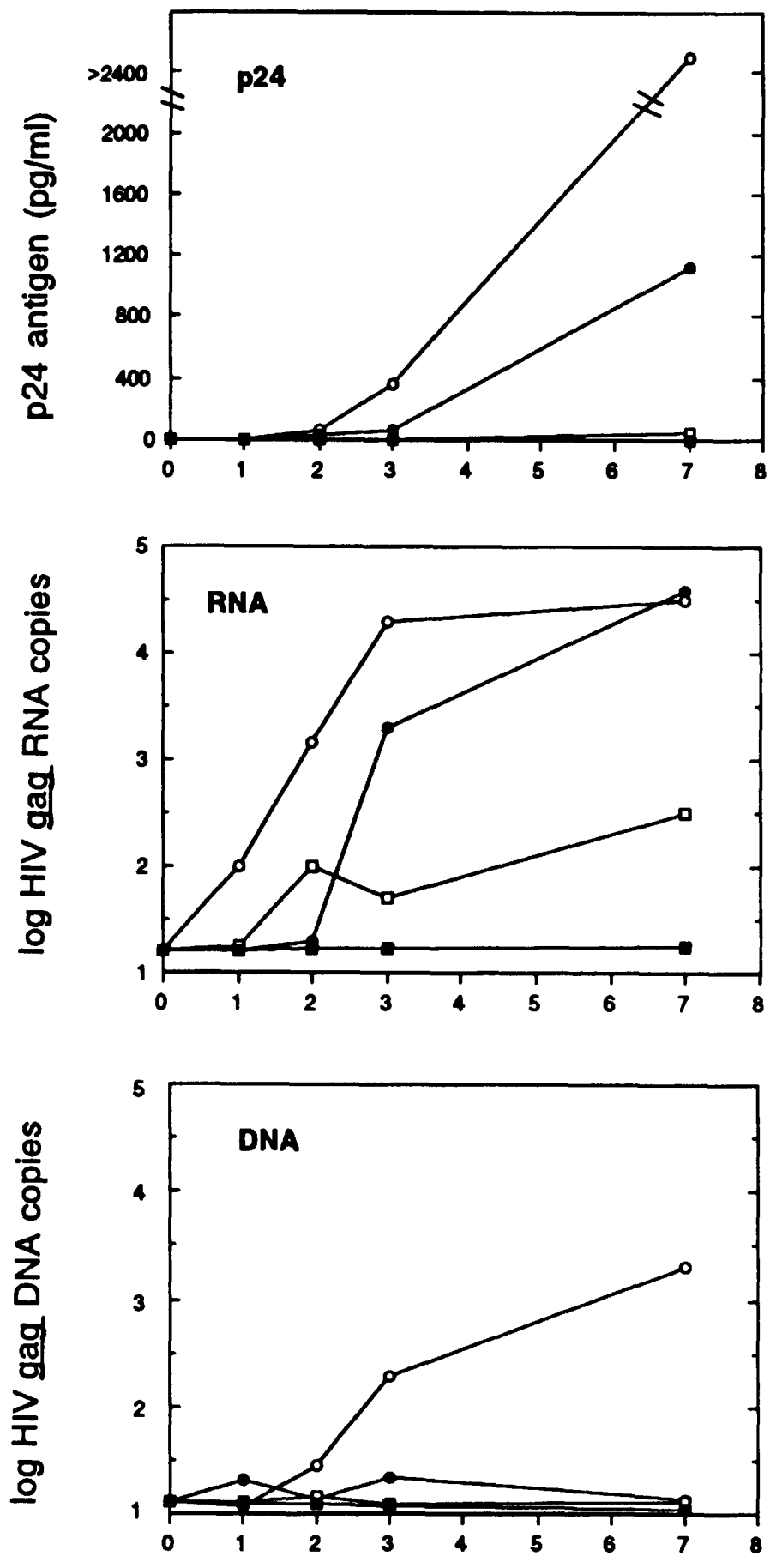

\section{HIV Strain 691}
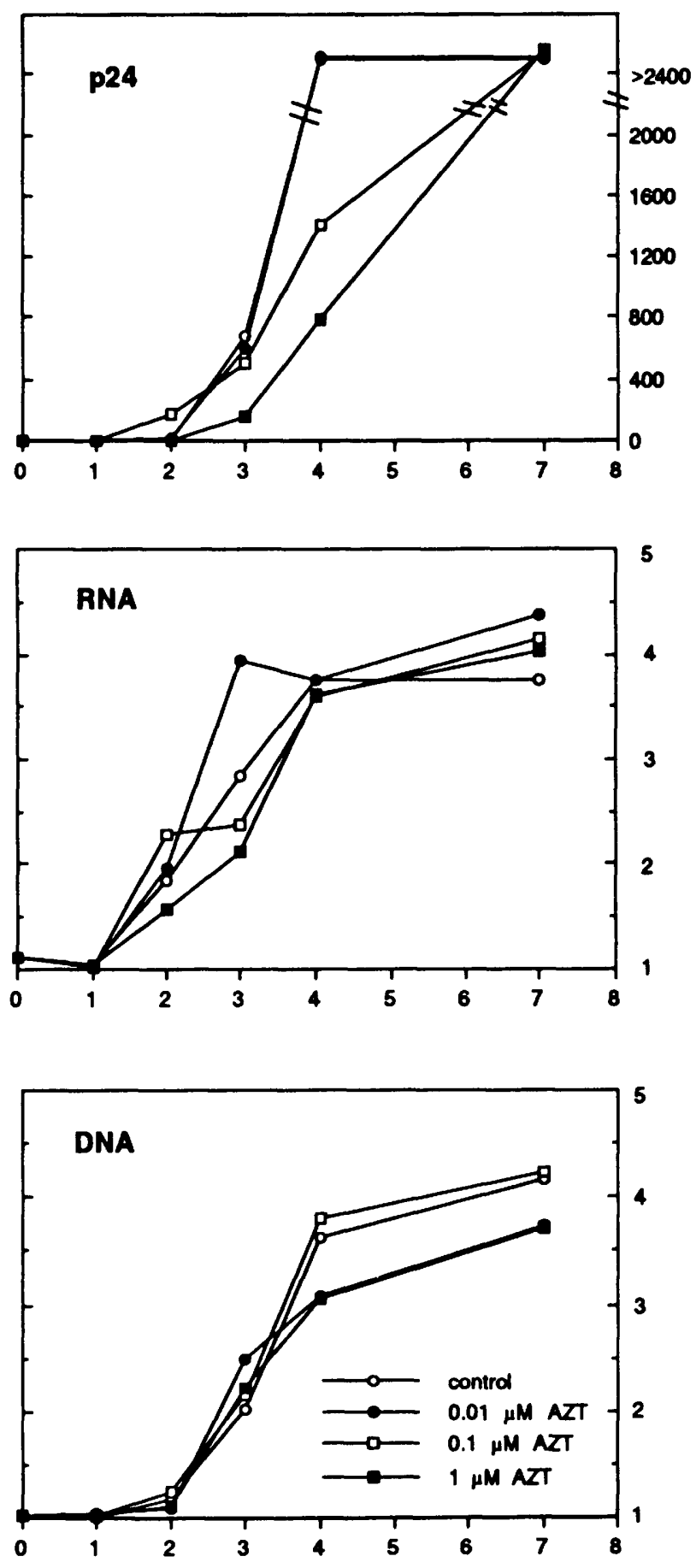

Day After Infection

FICURE 1 Replication of 100 TCID of HIV strain IIIb and strain 691 in PHA blasts. PHA-stimulated normal PBMC were infected with HIV strain IIIb or strain 691 in the presence of various concentrations of AZT. Cells and supernatant were sampled from each culture and assayed for p24 antigen, HIV gag RNA, and HIV gag DNA. Each point represents a single p24 determination or a single amplification of $1 \mu g$ of cellular DNA or reverse-transcribed cellular RNA. 
applied to an in vitro assay system to measure viral replication and antiviral activity. Further assessment of the effect of multiplicity of infection, inherent viral growth rate, host cell characteristics, and intertest variability will be required to develop this type of assay system into a quantitative measure of drug susceptibility. In addition to measuring directly the ability of a drug to inhibit viral replication, RNA and DNA quantitation can also provide preliminary information regarding mechanism of drug action. Although the current cost (labor and materials) of performing PCR evaluations of RNA and DNA samples is greater than performing p24 antigen measurements,

\section{Patient L2}
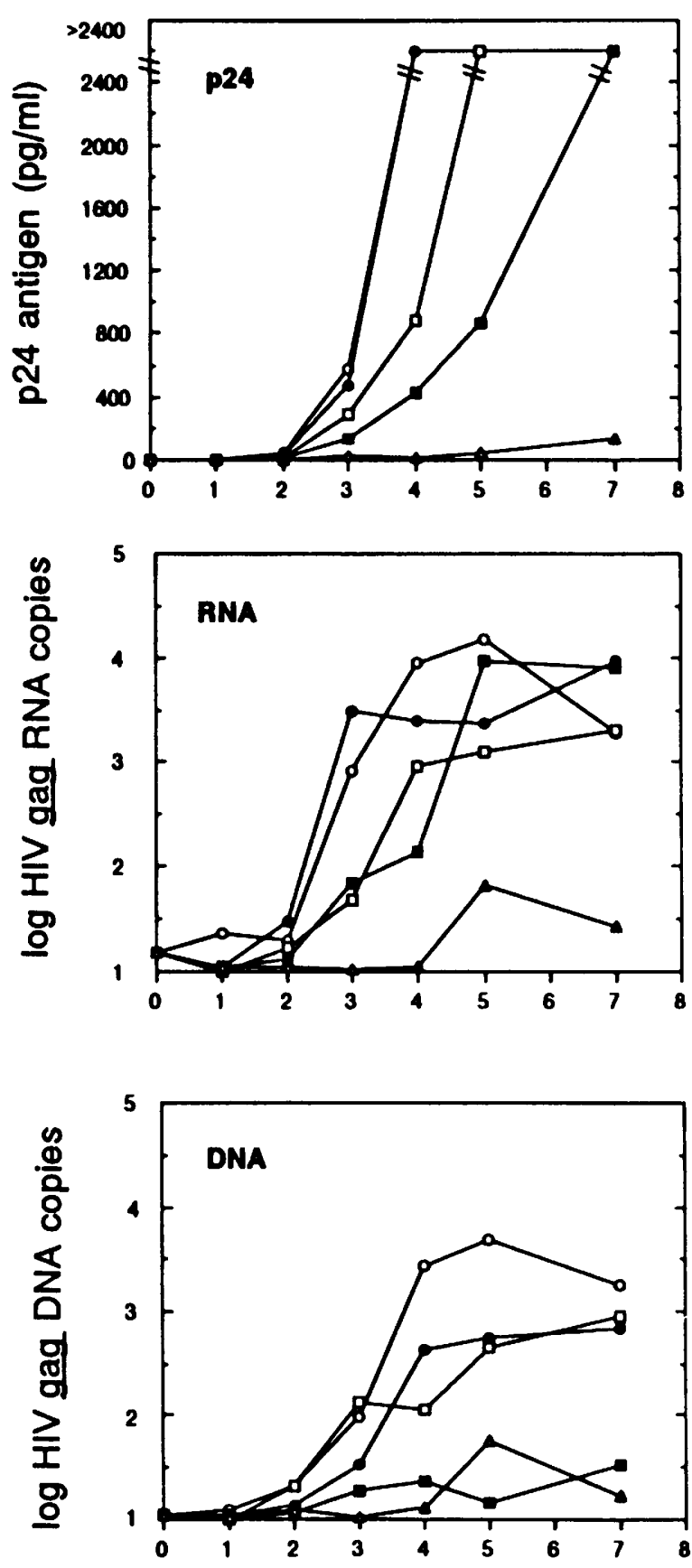

Patient JR
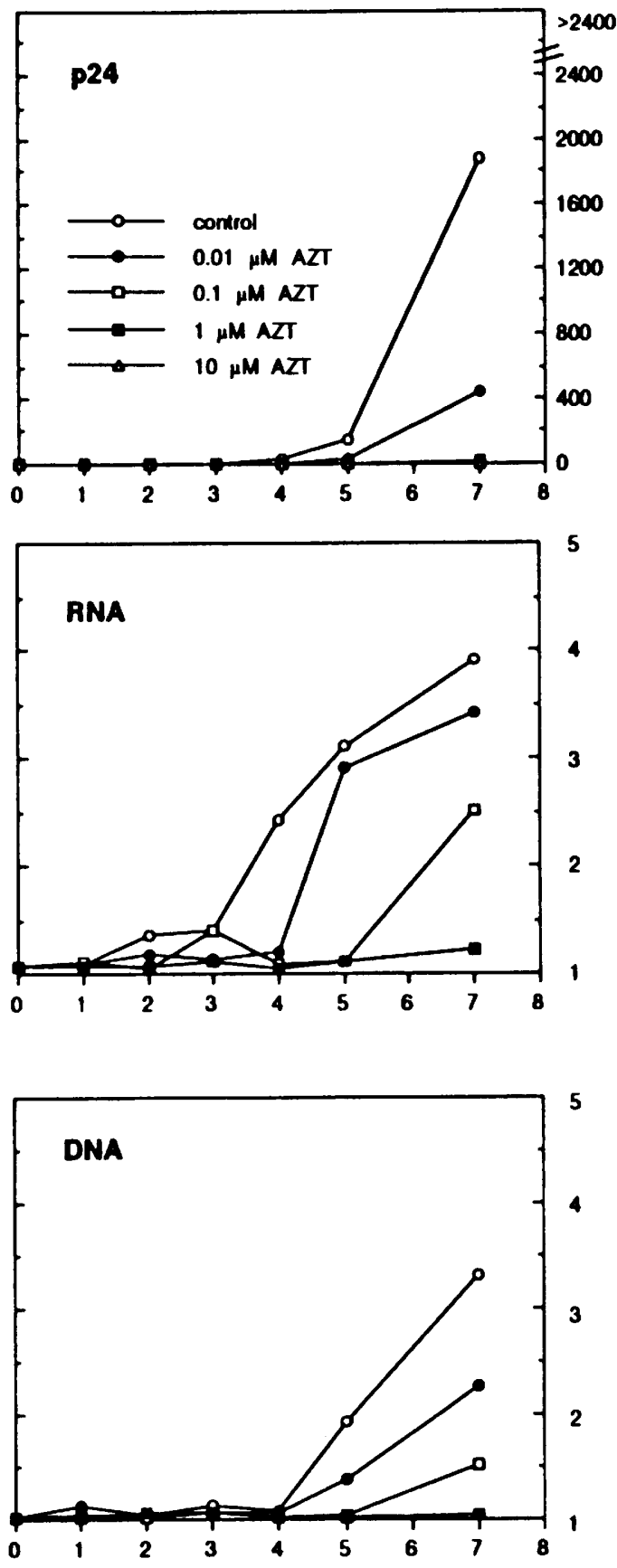

\section{Day After Infection}

FIGURE 2 Replication of patient-derived HIV in PHA blasts. PHA-stimulated normal PBMC were infected with 100 TCID of patient isolate L2 or 50 TCID of HIV patient isolate JR in the presence various concentrations of AZT. Cells and supernatant were sampled from each culture and assayed for p24 antigen, HIV gag RNA, and HIV gag DNA. Each point represents a single p24 determination or a single amplification of $1 \mu \mathrm{g}$ of cellular DNA or reverse-transcribed cellular RNA. 
the development of automated equipment and techniques ${ }^{(15)}$ may provide simple and relatively inexpensive means to evaluate HIV replication by quantitating nucleic acids.

\section{ACKNOWLEDGMENTS}

This work was supported by Public Health Service Grant AI-27762 from the National Institutes of Health.

\section{REFERENCES}

1. Johnson, V.A., M.A. Barlow, T. Chou, R.A. Fisher, B.D. Walker, M.S. Hirsch, and R.T. Schooley. 1989. Synergistic inhibition of human immunodeficiency virus type 1 (HIV-1) replication in vitro by recombinant soluble CD4 and $3^{\prime}$-azido-3'-deoxythymidine. J. Infect. Dis. 159: 837-844.

2. Land, S., G. Treloar, D. McPhee, C. Birch, R. Doherty, D. Cooper, and I. Gust. 1989. Decreased in vitro susceptibility to zidovudine of HIV isolates obtained from patients with AIDS. J. Infect. Dis. 161: 326-329.

3. Gendelman, H.E., L.M. Baca, J. Turpin, D.C. Kalter, B. Hansen, J.M. Orenstein, C.W. Dieffenbach, R.M. Friedman, and M.S. Meltzer. 1990. Regulation of HIV replication in infected monocytes by IFN- $\alpha$. I. Immunol. 145: 2669-2676.

4. Stevenson, M., T.L. Stanwick, M.P. Dempsey, and C.A. Lamonica. 1990. HIV-1 replication is controlled at the level of $\mathrm{T}$ cell activation and proviral integration. EMBO J. 9: 1551-1560.

5. Kim, S.D. Ikeuchi, R. Byrn, J. Groopman, and D. Baltimore. 1989. Lack of a negative influence on viral growth by the nef gene of human immunodeficiency virus type 1 . Proc. Natl. Acad. Sci. 86: 9544-9548.

6. Ma, X., D. Sakai, F. Sinangil, E. Golub, and D. J. Volsky. 1990. Interaction of a noncytopathic human immunodeficiency virus type 1 (HIV-1) with target cells: Efficient virus entry followed by delayed expression of its RNA and protein. Virology 176: 184-194.

7. Somasundaran, M. and H.L. Robinson. 1989. Unexpectedly high levels of HIV-1 RNA and protein synthesis in a cytocidal infection. Science 242: 1554-1557.

8. Bell, J. and L. Ratner. 1989. Specificity of polymerase chain amplification reactions for human immunodefic- iency virus type 1 DNA sequences. AIDS Human Retro. 5: 87-95.

9. Drone, W.J.A., J.J. Sninsky, and J. Goudsmit. 1990. Detection and characterization of HIV-1 by polymerase chain reaction. J. AIDS 3: 517-524.

10. Lee, T., F.J. Sunzeri, L.H. Tobler, B.G. Williams, and M.P. Busch. 1991. Quantitative assessment of HIV-1 DNA load by coamplification of HIV. 1 gag and HLA-DQ- $\alpha$ genes. AIDS 5: 683-691.

11. Oka, S., K. Urayama, Y. Hirabayashi, K. Ohnishi, H. Goto, K. Mitamura, S. Kimura, and K. Shimada. 1991. Quantitative estimation of human immunodeficiency virus type-1 provirus in CD4+ $\mathrm{T}$ lymphocytes using the polymerase chain reaction. Mol. Cell. Probes 5: 137-142.

12. Poznansky, M.C., B. Walker, W.A. Haseltine, J. Sodroski, and E. Langhoff. 1991. A rapid method for quantitating the frequency of peripheral blood cells containing HIV-1 DNA. I. AIDS 4: 368-373.

13. Larder, B.A., G. Darby, and D.D. Richman. 1989. HIV with reduced sensitivity to zidovudine (AZT) isolated during prolonged therapy. Science 243: 1731-1734.

14. Chomczynski, P. and N. Sacchi. 1987. Single step method of RNA isolation by acid guanidinium thiocyanatephenol-chloroform extraction. Anal. Biochem. 162: 156-159.

15. Holodniy, M., M.A. Winters, and T.C. Merigan. 1992. Detection and quantification of gene amplification products by a nonisotopic automated system. BioTechniques 12: 36-39.

16. Holodniy, M, D.A. Katzenstein, S. Sengupta, and T.C. Merigan. 1991. Quantification of HIV RNA in patient serum using the polymerase chain reaction. J. Infect. Dis. 163: 862-866.

17. Dickover, R.E., R.M. Donovan, R. Goldstein, S. Dandekar, C.D. Bush, and J.R. Carlson. 1990. Quantitation of human immunodeficiency virus DNA by using the polymerase chain reaction. J. Clin. Microbiol. 28: 21302133.

18. Oka, S., K. Urayama, Y. Hirabayshi, K. Ohnishi, H. Goto, K. Mitamura, S. Kimura, and K. Shimada. 1990. Quantitative analysis of human immunodeflciency virus type 1 in asymptomatic carriers using the polymerase chain reaction. Biochem.
Biophys. Res. Commun. 167: 1-8.

19. Keller, H.H., D.P. Huang, and M.M. Manak. 1991. Detection of human immunodeficiency virus type 1 DNA by polymerase chain reaction amplification and capture hybridization in microtiter wells. J. Clin. Microbiol. 29: 638-641.

20. Mitsuya, H., R. Yarchoan, and S. Broder. 1990. Molecular targets for AIDS therapy. Science 249: 15331542.

Received October 17, 1991; accepted in revised form February 4, 1992. 


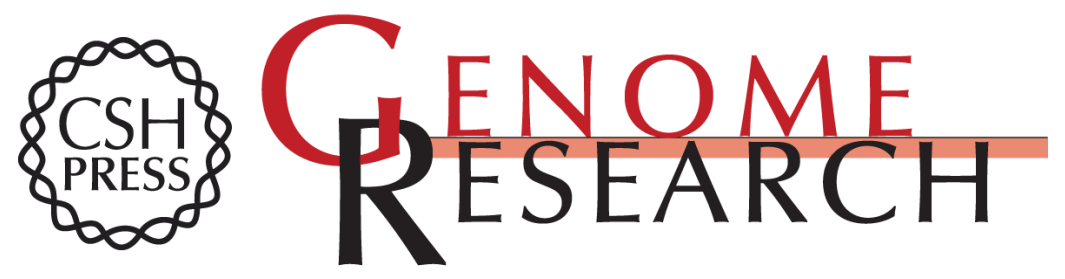

\section{Quantitative RNA and DNA gene amplification can rapidly monitor HIV infection and antiviral activity in cell cultures.}

M A Winters, M Holodniy, D A Katzenstein, et al.

Genome Res. 1992 1: 257-262

Access the most recent version at doi:10.1101/gr.1.4.257

References This article cites 20 articles, 6 of which can be accessed free at:

http://genome.cshlp.org/content/1/4/257.full.html\#ref-list-1

\section{License}

Email Alerting Receive free email alerts when new articles cite this article - sign up in the box at the Service top right corner of the article or click here.

\section{Affordable, Accurate Sequencing.}

To subscribe to Genome Research go to:

https://genome.cshlp.org/subscriptions 